\title{
Krzysztof Flasiński
}

Uniwersytet Szczeciński

\section{Kościół katolicki i jego społeczność na łamach serwisu internetowego „Gazety Wyborczej" podczas epidemii COVID-19}

\author{
The Catholic Church and the Catholic community \\ on the "Gazeta Wyborcza" news website \\ during the COVID-19 epidemic
}

\begin{abstract}
ABSTRAKT
Celem badania było ustalenie sposobu przedstawienia tematyki związanej z Kościołem katolickim i wiernymi
\end{abstract} w internetowym serwisie „Gazety Wyborczej” w okresie pandemii COVID-19, od 14.01 do 10.10.2020 r. Materiał badawczy składał się z 1381 artykułów (5,65 proc. wszystkich newsów dotyczących COVID-19). Średnio dziennie ukazywało się 5 tekstów dotyczących analizowanego tematu, najwięcej (od 35 do

39) w okresie od 12 do 15 marca. Analiza jakościowa wykazała, że badany temat był stale obecny na łamach wyborcza. pl, był traktowany przeważnie w sposób neutralny. Zdecydowanie przeważały teksty informacyjne na temat ograniczeń dotykających wiernych, ale również wszystkich czytelników, niezależnie od wyznania. Informacje miały silny charakter lokalny. Materiały reportażowe dotyczyły głównie akcji pomocy dla najbardziej potrzebujących.

SŁOWA KLUCZOWE: dziennikarstwo, wizerunek, Gazeta Wyborcza, religia, COVID-19, Kościół katolicki

\begin{abstract}
The aim of the study was to determine the method of presenting topics related to the Catholic Church, and the community on the website of "Gazeta Wyborcza" during the COVID-19 pandemic, in the period from 14/01 to $10 / 10 / 2020$. The research material contained 1,381 articles (5.65 percent of all COVID-19 news). On average, 5 texts on the research topic were published daily, the most (from 35 to 39) from March 12 to 15 . The qualitative analysis showed that the examined topic was constantly present on wyborcza.pl, and it was treated mostly in a neutral manner. Informative texts on the limitations affecting the Catholic community, but also all readers, regardless of religion, dominated. The news was mostly local. The reportage texts concerned the aid actions for people who need support.
\end{abstract}

\section{KEYWORDS:}

journalism, image, Gazeta Wyborcza, religion, COVID-19, Catholic Church 
$\mathrm{W}$ przypadku każdej epidemii szczególna uwaga zwracana jest na duże zbiorowiska ludzi. W naturalny sposób mieszczą się w tej kategorii wydarzenia o charakterze religijnym, przede wszystkim nabożeństwa. W literaturze wskazuje się, że są one łączone - zarówno przez naukę, jak i przez media - z rozprzestrzenianiem się chorób. Szczególnie widoczne było to podczas pandemii grypy hiszpanki w 1917 r., kiedy „frekwencja w kościołach wzrosła pomimo rady, aby wstrzymać publiczne zgromadzenia [...]. Po tygodniowej serii wydarzeń religijnych ku czci Najświętszej Marii Panny, choroba rozprzestrzeniła się w mieście Zamora w szybkim tempie i odnotowała najwyższy wskaźnik śmiertelności wśród dużych miast w Hiszpanii"1. Współczesnym przykładem może być pogrzeb przywódcy religijnego w Liberii w 2017 r., którego uczestnicy zachorowali na gorączkę krwotoczną Ebola $^{2}$. W przypadku pandemii COVID-19 w Korei Południowej media wskazywały na rolę, jaką w rozprzestrzenianiu się choroby w tym kraju mogło odegrać tajne nabożeństwo jednego z ruchów religijnych, w którym udział brała osoba zarażona wirusem, określana jako „pacjent 31”3. Jakkolwiek wydarzenia o charakterze religijnym przyczyniają się do rozwoju epidemii ze względu na zgromadzenie w jednym miejscu wielu osób, media zauważają, że inne imprezy masowe odnoszą podobny skutek. Najbardziej jaskrawym przykładem był mecz piłkarski Bergamo z 19 lutego 2020 r., który przez dziennikarzy - cytujących epidemiologów i lekarzy - był nazywany „momentem zero pandemii”4 czy „bombą biologiczną”.

${ }^{1} \mathrm{~J}$. Breitnauer, The Spanish flu epidemic and its influence on history. Stories from the 19181920 global flu pandemic, Pen \& Sword History, Barnsley 2019, s. 43.

${ }^{2}$ Ch. Lynteris, Human extinction and the pandemic imaginary, Routledge, Londyn 2020, s. 33.

${ }^{3}$ H. Shin, H. Young Yi, Secretive church at center of South Korea's explosive coronavirus outbreak, Reuters z 27.02.2020, https://www.reuters.com/article/us-china-health-southkorea-church/secretive-church-at-center-of-south-koreas-explosive-coronavirus-outbreakidUSKCN20L0Q8 (dostęp 1.10.2020 r.).

${ }^{4}$ M. Mazzini, Od tego się zaczął włoski dramat? Wirus na stadionie, Polityka z 24.03.2020, https://www.polityka.pl/tygodnikpolityka/swiat/1949048,1,od-tego-sie-zaczal-wloskidramat-wirus-na-stadionie.read (dostęp 1.10.2020 r.); T. Azzoni, A. Dampf, Game Zero: Spread of virus linked to Champions League match, The Associated Press, 25.02.2020, https://apnews. com/article/ae59cfc0641fc63afd09182bb832ebe2 (dostęp 1.10.2020 r.).

${ }^{5}$ A. Nicolaides, Członek WHO potwierdza: To wydarzenie rozprzestrzeniło koronawirusa, Radio Zet z 25.03.2020, https://sport.radiozet.pl/Pilka-nozna/Liga-Mistrzow/WHO-potwierdza-Mecz-Atalanta-Valencia-rozprzestrzenil-koronawirusa (dostęp 1.10.2020 r.); D. Bieler, 'A biological bomb': Champions League match in Italy linked to epicentre of coronavirus outbreak, The Independent z 25.03.2020, https://www.independent.co.uk/news/world/ 
Odniesienia religijne były również często wykorzystywane do zobrazowania rozmiarów epidemii. We wspomnieniach z okresu hiszpanki pojawiają się opisy nabożeństw pogrzebowych, kiedy w kościołach trumny stały ułożone jedna na drugiej ${ }^{6}$. Mimo że współcześnie często funkcję tę pełnią fotografie i nagrania wideo (np. wstrząsające obrazy przedstawiające pogrzeby ofiar wirusa SARS-CoV-2 w masowych grobach na wyspie Hart w Nowym Jorku, które obiegły świat w kwietniu 2020 r. $^{7}$ ), także dzisiaj metaforyka, związana z Dniem Ostatecznym i Apokalipsą, jest używana przez dziennikarzy opisujących epidemie ${ }^{8}$ - szczególnie w tekstach uwypuklających emocje w miejsce informacji.

\section{MATERIAL BADAWCZY I METODA ANALIZY}

Celem badania było ustalenie sposobu przedstawienia tematyki związanej Kościołem i wiernymi w internetowym serwisie „Gazety Wyborczej” w okresie pandemii COVID-19.

Do analizy wybrano publikacje, które ukazały się w ogólnoinformacyjnym serwisie wyborcza.pl - internetowym wydaniu dziennika "Gazeta Wyborcza”. Okres analizy ustalono na czas od 14 stycznia (data ukazania się pierwszego tekstu na temat COVID-19 w 2020 r.) do 10 października 2020 roku (dzień ogłoszenia nowych, restrykcyjnych ograniczeń związanych z tzw. drugą falą pandemii). Skompletowano korpus 24541 tekstów, których tematyka nawiązywała do choroby COVID-19. Z korpusu wyodrębniono materiały, które zawierały ustalone podczas badań pilotażowych słowa kluczowe, wskazujące na odniesienia do Kościoła katolickiego i jego wspólnoty. Na podstawie obecności słów kluczowych ${ }^{9}$

coronavirus-italy-champions-league-atlanta-valencia-milan-bergamo-a9426616.html (dostęp $1.10 .2020 \mathrm{r}$.).

${ }^{6} \mathrm{M}$. Honigsbaum, Living with Enza. The forgotten story of Britain and the great flu pandemic of 1918, Springer, Basingstoke 2016, s. 132.

${ }^{7} \mathrm{~J}$. Yuan, Burials on Hart Island, where New York's unclaimed lie in mass graves, have risen fivefold, The Washington Post z 16.04.2020, https://www.washingtonpost.com/national/ hart-island-mass-graves-coronavirus-new-york/2020/04/16/a0c413ee-7f5f-11ea-a3ee-13e1ae0a3571_story.html (dostęp 1.10.2020 r.).

${ }^{8}$ S. D. Moeller, Compassion fatigue. How the media sell disease, famine, war and death. Routledge, Nowy Jork 2002, s. 64.

${ }^{9}$ Lista słów kluczowych wg frekwencyjności występowania w materiale badawczym: kościół (425 wystąpień), ksiądz (357), msza (347), biskup (302), parafia (215), wierni (207), święta (195), Wielkanoc (185), diecezja (123), komunia (122), zakon (107), proboszcz (96), 
(łącznie z formami i obocznościami gramatycznymi) stworzono zestaw tekstów, niżej określany jako materiał badawczy.

Materiał badawczy poddano analizie ilościowej, która pokazuje zmiany w liczbie publikowanych tekstów w czasie. Analiza jakościowa pozwoliła, w bardziej szczegółowy sposób, przyjrzeć się sposobowi przedstawienia problematyki w badanych artykułach.

\section{WYNIKI ANALIZY ILOŚCIOWEJ}

Jak wspomniano we wstępie, w okresie 14.01-10.10 (czyli podczas 271 dni) w serwisie „Gazety Wyborczej” ukazało się łącznie 24541 materiałów dziennikarskich, które były powiązane tematycznie z pandemią COVID-19, z czego 1381 (czyli 5,65 proc.) zawierało odniesienia do Kościoła lub jego wiernych. Średnio dziennie ukazywało się 5 takich artykułów (średnia dla korpusu: 90,65), przy medianie 3 (dla korpusu: 67). Podczas 47 dni nie ukazał się żaden news związany z pandemią i jednocześnie dotyczący analizowanego tematu. Najwięcej takich tekstów publikowano od 12 do 15 marca, odpowiednio: 37, 39, 39 i 35 artykułów.

\section{Od 14 stycznia do 10 października w serwisie "Gazety Wyborczej" ukazało się łącznie 24 541 materiałów dziennikarskich, które były powiązane tematycznie z pandemią COVID-19, z czego 1381 zawierało odniesienia do Kościoła lub wiernych.}

Bóg (88), modlitwa (85), nabożeństwo (83), pogrzeb (81), ślub (80), pielgrzym (77), cmentarz (74), kuria (67), duchowny (66), dyspensa (63), święcenie (63), episkopat (53), klasztor (48), rekolekcje (47), katedra (46), papież (46), kapłan (41), religia (41), procesja (37), Caritas (36), katolik (31), bazylika (28), świątynia (27), kaplica (26), Watykan (25), spowiedź (22), bierzmowanie (21), duszpasterz (20), liturgia (17), sanktuarium (16), sakrament (15), wiara (15), wikary (14), Ewangelia (13), Posługa (13), błogosławieństwo (12), prymas (12), chrzciny (10), kler (10), pleban (10), apostoł (8), Eucharystia (8), katecheta (8), chrześcijanin (6), kolęda (6), kardynał (5), homilia (4). 
Poniższe wykresy ilustrują liczbę publikacji poruszających tematykę religijno-kościelną w analizowanym okresie oraz ich odsetek w stosunku do wszystkich tekstów dotyczących pandemii.

Wykres nr 1 pokazuje, że liczba tematycznych publikacji była wyraźnie najwyższa w okresie wprowadzenia pierwszych surowych restrykcji, czyli w drugiej połowie marca i na początku kwietnia. Ten wynik jest zgodny z rozkładem ogólnej liczby materiałów dziennikarskich odnoszących się do COVID-19. W połowie kwietnia można zauważyć kolejny wzrost liczby informacji, który łączy się z uroczystościami świąt Wielkiej Nocy. Niewielki wzrost 6.10 spowodowany był dyskusją w mediach na temat sposobu obchodów dnia Wszystkich Świętych.

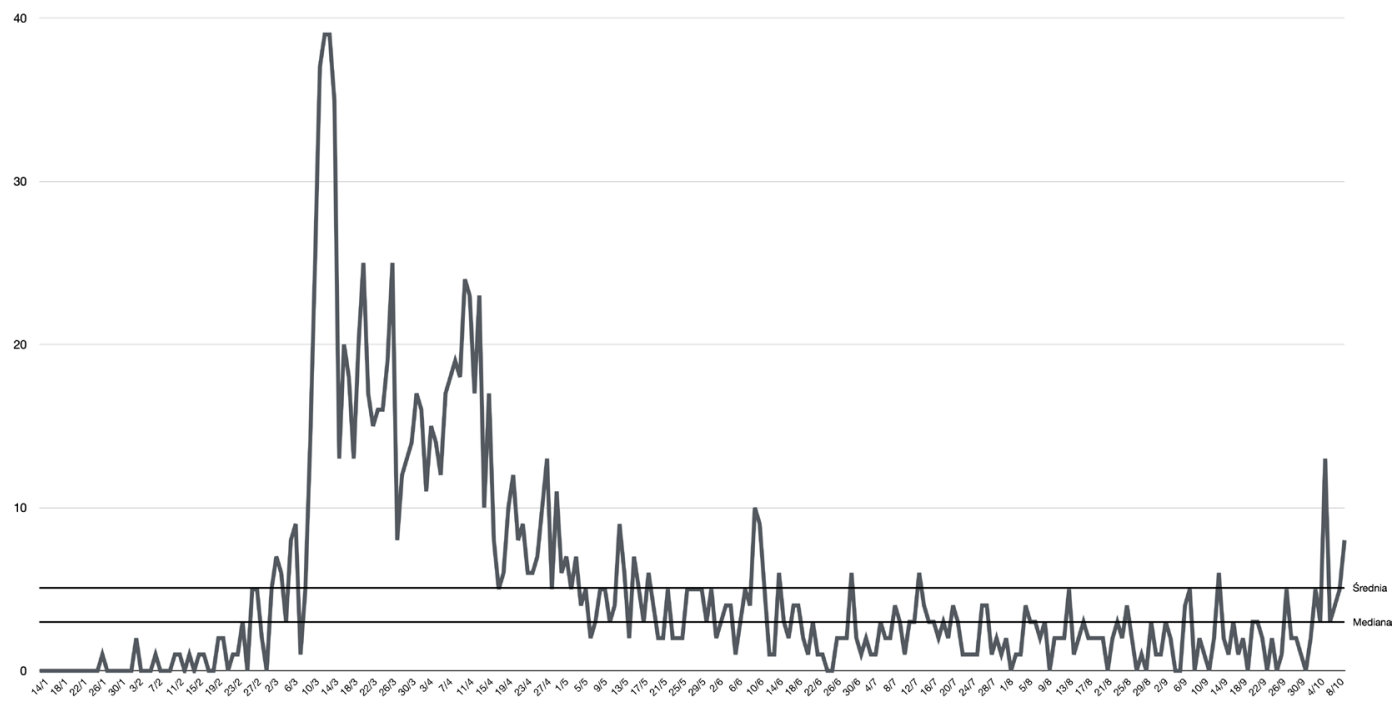

Ryc. 1: Liczba publikacji poruszających temat pandemii COVID-19 oraz zawierających odwołania do Kościoła i wspólnoty w serwisie „Gazety Wyborczej” w okresie 14.01-10.10.2020 średnia $=5$, mediana $=3$

Źródło: badania własne

Na wykresie nr 2 zaprezentowano procentowy udział analizowanych tekstów w korpusie.

W odróżnieniu od liczebności tekstów ich udział procentowy w korpusie jest stosunkowo równomierny. Z wyjątkiem okresu świątecznego odsetek ten pozostaje zbliżony do 5 proc., sporadycznie osiągając wynik dwucyfrowy. 


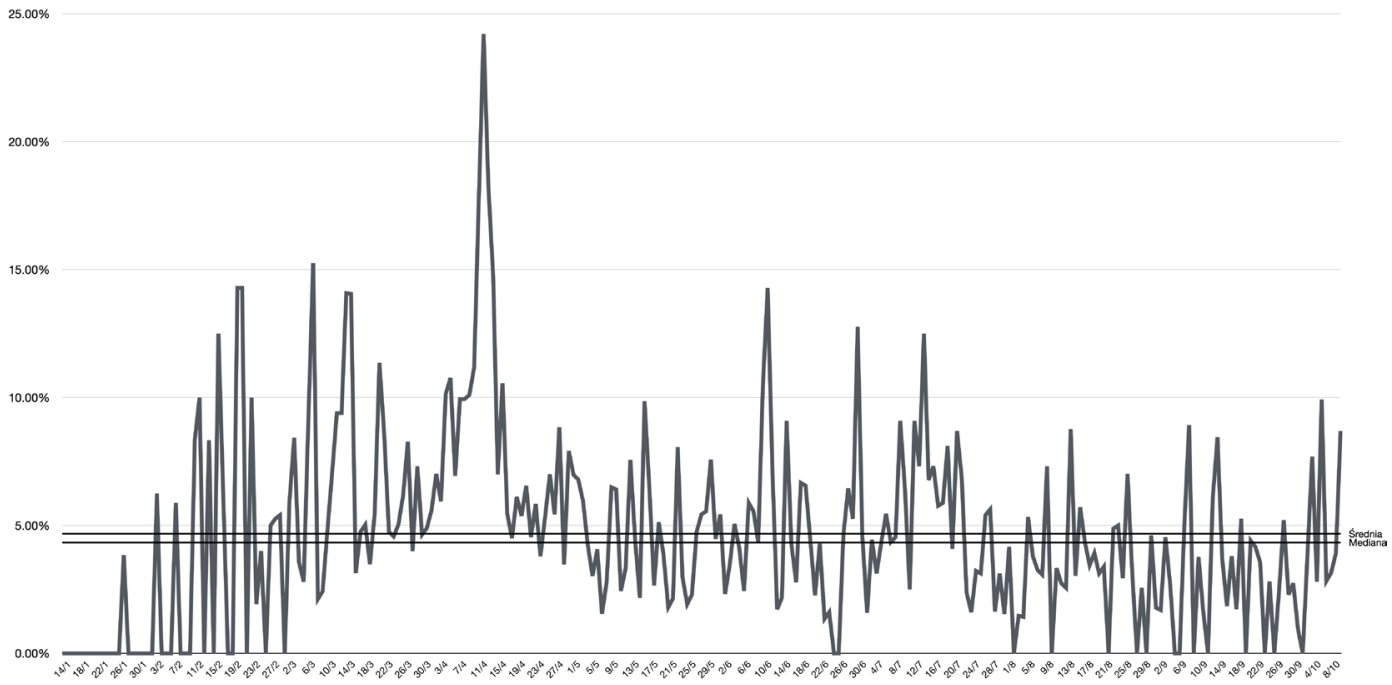

Ryc. 2: Odsetek publikacji zawierających odwołania do Kościoła i wspólnoty w stosunku do całości tekstów na temat pandemii COVID-19 w serwisie „Gazety Wyborczej” w okresie 14.01-10.10.2020 średnia $=4,68$ proc., mediana $=4,35$ proc.

Źródło: badania własne

Wydarzenia wpływające na zaprezentowane powyżej wyniki zostaną opisane szczegółowo w dalszej części artykułu.

\section{ANALIZA JAKOŚCIOWA}

W celu zbudowania pełnego obrazu obecności badanej tematyki w serwisie wyborcza.pl przeprowadzono analizę jakościową materiału badawczego. Badano tematykę publikacji, lokalność wiadomości (międzynarodowe, ogólnopolskie, lokalne), przynależność genologiczną (informacja, publicystyka) ${ }^{10}$, występowanie sygnałów świadczących o stronniczości występującej w artykułach

${ }^{10}$ Zastosowano najbardziej ogólny podział na teksty informacyjne i publicystyczne. Do drugiej grupy zakwalifikowano materiały dziennikarskie zawierające sygnały gatunkowe typowe dla publicystyki, jak wyrażanie własnych opinii autora, pogłębienie analizy, interpretacje faktów, tendencyjne naświetlenie zjawiska społecznego, prezentowanie emocji, puentowanie wypowiedzi, stawianie pytań (K. Wolny-Zmorzyński, A. Kaliszewski, J. Snopek, W. Furman, Prasowe gatunki dziennikarskie, Poltext, Warszawa 2014, s. 19-23). 
(stronnicze, neutralne) ${ }^{11}$ oraz wydźwięk artykułów (pozytywny, negatywny lub neutralny). Jako decydujące kryterium wybrano temat poruszany $\mathrm{w}$ materiale dziennikarskim.

Publikacje pogrupowano w trzech zestawach:

(1) teksty na temat ograniczeń wpływających na życie Kościoła i wiernych,

(2) artykuły dotyczące pomocy dla potrzebujących, organizowanej przez instytucje kościelne,

(3) materiały związane z bezpieczeństwem w kościołach i prezentujące kontrowersyjne wydarzenia i wypowiedzi.

Do wymienionych wyżej grup zakwalifikowano odpowiednio 1285,22 oraz 74 teksty. Wysoka liczba tekstów w pierwszym zestawie wynika z dwóch przyczyn. Po pierwsze, w analizowanym okresie redakcja wykazywała szczególną aktywność, która przełożyła się na ogólną liczbą materiałów opublikowanych w serwisie wyborcza.pl. Po drugie, kwestie związane z ograniczeniem praktyk religijnych były poruszane łącznie z problemami dotyczącymi innych dziedzin życia, co dodatkowo przełożyło się na liczebność tego zestawu tekstów. Przyczyną niższych wskaźników w kolejnych grupach jest bardziej jakościowe, publicystyczne podejście do opisywanych wydarzeń - miejsce krótkich newsów zajęły bardziej rozbudowane materiały dziennikarskie.

\section{(1) OGRANICZENIA W ODBYWANIU PRAKTYK RELIGIJNYCH}

W analizowanym okresie najszerzej relacjonowane były skutki kolejnych ograniczeń liczby osób przebywających w kościołach. W początkowym okresie dominowały,

${ }^{11} \mathrm{~W}$ zakresie badania stronniczości (media bias) tekstów prasowych analizy dotyczą najczęściej tematyki związanej z polityką (m.in.: K. Brzoza, D. Głuszek-Szafraniec, P. Szostok, Upolitycznienie przekazu prasowego $w$ wybranych polskich tygodnikach opinii. Wstępny raport z badań, „Political Preferences” 2017 nr 16, s. 81-106). Badania nachylenia światopoglądowego w tekstach dotyczących Kościoła katolickiego prowadzono w większości na materiale złożonym tylko z artykułów publicystycznych (m.in. A. Kubacka, Wartościowanie Kościoła czy Kościół jest wartością?, „Słowo. Studia Językoznawcze” 2019 nr 10, s. 94-101; Poniński A., O Kościele w „Gazecie Wyborczej” w latach 1989-1993, „Studia Włocławskie” 2005 nr 7, s. 267276). Jako materiały neutralne zakwalifikowano teksty, które nie zawierały komentarzy odautorskich, wyrażonych wprost wypowiedzi wartościujących lub takie, w których umieszczono oceny zarówno pozytywne, jak i negatywne, zachowując zasadę równowagi (M. Kunczik, A. Zipfel, Wprowadzenie do nauki o dziennikarstwie i komunikowaniu, tłum. J. Łoziński, W. Łukowski, Scholar, Warszawa 2000, s. 105-112). 
z oczywistych powodów, doniesienia z zagranicy. Od połowy marca publikowano informacje na temat decyzji zarówno Konferencji Episkopatu Polski ${ }^{12}$, jak i poszczególnych biskupów ${ }^{13}$.

W tekstach opisywano ograniczenia w poszczególnych diecezjach ${ }^{14}$ lub nawet sytuacje w konkretnych kościołach (tak jak w parafii św. Jacka w Rzeszowie: „podjęliśmy trudną decyzję o zawieszeniu publicznego sprawowania Eucharystii w naszym kościele [...]. Jak tłumaczą dominikanie, nie są w stanie spełnić wymogów bezpieczeństwa"15). W późniejszym okresie coraz więcej informacji dotyczyło zamknięcia poszczególnych świątyń.

Powszechna w wielu dziedzinach życia społecznego, dyskusja na temat możliwości wykorzystania komunikacji zdalnej nie ominęła Kościoła, początkowo za granicą, następnie również w Polsce. 5.03 ukazał się artykuł, w którym opisano telewizyjne transmitowanie mszy świętych odprawianych w pustych kościołach we Włoszech oraz uczestnictwo w nabożeństwach za pośrednictwem internetu w Hong Kongu ${ }^{16}, 14.03$ - tekst poradniczy ze wskazówkami dotyczącymi korzystania z transmisji nabożeństw ${ }^{17}$.

W okresie Wielkiej Nocy publikowano materiały streszczające nabożeństwa online. Ich osią były kazania wygłaszane przez biskupów. Przykładem może być tekst, w którym abp Grzegorz Ryś, metropolita łódzki, mówi: „Zamknąłem oczy, by zobaczyć katedrę wypełnioną ludźmi. Widzę was wszystkich, którzy tu jesteście duchowo"18.

${ }^{12} \mathrm{~Np} .:$ https://katowice.wyborcza.pl/katowice/7,35063,25781560,msze-sw-zostana-w-kosciolach-odwolane-decyzja-bedzie-rozwazana.html

${ }^{13} \mathrm{~Np}$. https://bialystok.wyborcza.pl/bialystok/7,35241,25789375,koronawirus-metropolita-bialostocki-wprowadza-ograniczenia.html; https://bydgoszcz.wyborcza.pl/bydgoszcz/7,48722,25791078,koronawirus-w-bydgoskich-kosciolach-po-dziesiec-osob-na-mszy. html; https://szczecin.wyborcza.pl/szczecin/7,34939,25789012,koronawirus-abp-dziega-daje-dyspense-na-msze-i-odwoluje-bierzmowania.html

${ }^{14}$ Np. https://krakow.wyborcza.pl/krakow/7,44425,25828166,koronawirus-puste-koscioly-katolicy-przygotowuja-sie-do-wielkanocy.html

${ }^{15}$ https://rzeszow.wyborcza.pl/rzeszow/7,34962,25789974,koronawirus-dominikanie-z-rzeszowa-odwoluja-msze-i-spowiedz.html

${ }^{16}$ https://wyborcza.pl/7,75399,25760361,koronawirus-zmienia-praktyki-religijne-msze-online-odwolane.html

${ }^{17}$ https://torun.wyborcza.pl/torun/7,48723,25787158,koronawirus-msze-online-godzina-po-godzinie-nie-tylko-z-polski.html

${ }^{18}$ https://lodz.wyborcza.pl/lodz/7,35136,25859677,abp-grzegorz-rys-w-wielki-czwartek-zamknalem-oczy-by-zobaczyc.html 
Więcej pytań, niż zdalne uczestnictwo w nabożeństwie, wywołały wątpliwości na temat spowiedzi online. Obszernie cytowany był ks. dr Przemysław Szewczyk z parafii pw. św. Alberta Chmielowskiego w Łodzi, który tłumaczył, że „brak fizyczności i materialnego aspektu sprawia, że sakrament traci swoje fundamentalne narzędzie"19. W tym samym tekście ks. Paweł Kłys, rzecznik łódzkiej kurii, zwracał uwagę, że w konfesjonałach zamontowano folie ochronne, a z sakramentu spowiedzi można skorzystać na wolnym powietrzu. W podobnym tonie wypowiadali się wszyscy duchowni, powoływano się na przepisy obowiązujące cały Kościół katolicki ${ }^{20}$. Pojawiały się doniesienia o spowiedziach organizowanych w Lusówku pod Poznaniem i w Warszawie - dla kierowców, którzy mogą skorzystać z sakramentu, nie wysiadając z samochodu ${ }^{21}$.

Na osobne wyróżnienie zasługują artykuły na temat praktyk i zwyczajów religijnych, związanych ze świętami Wielkiej Nocy, które zbiegły się w czasie z największymi ograniczeniami, m.in. w poruszaniu się i zgromadzeniach publicznych.

Temat został wywołany cztery tygodnie przed Wielkanocą. 22.03 opublikowano tekst z zacytowanymi wskazaniami Kongregacji Kultu Bożego i Dyscypliny Sakramentów. W artykule, jako źródło potencjalnych problemów, nie są wskazani kapłani, ale wierni - niestosujący się do zaleceń22 ${ }^{2}$ Kolejne wskazówki na temat uczestnictwa w obchodach Triduum Paschalnego były podawane na bieżąco. Przytaczano wypowiedzi biskupów, którzy podkreślali otwarcie na potrzeby wiernych przy jednoczesnym podporządkowaniu się restrykcjom oraz zachowaniu środków ostrożności. W takim tonie cytowano np. pismo kurii diecezji warszawsko-praskiej:

Zaleca ograniczenie liczby uczestników we mszach według aktualnych wskazań organów państwowych. [...] W Wielki Czwartek i Wielki Piątek kapłani będą sprawowali mszę bez udziału wiernych. W Wielką Sobotę „należy umożliwić wiernym

${ }^{19}$ https://lodz.wyborcza.pl/lodz/7,35136,25803707,zbliza-sie-wielkanoc-czy-w-czasie-pandemii-koronawirusa-mozliwa.html

${ }^{20}$ https://katowice.wyborcza.pl/katowice/7,35063,25819225,wielkanoc-w-czasie-epidemii-abp-wiktor-skworc-nie-ma-pozwolenia.html

${ }^{21}$ https://poznan.wyborcza.pl/poznan/7,36001,25818669, koronawirus-spowiedz-na-kolkach-w-lusowku-nie-trzeba-nawet.html; https://warszawa.wyborcza.pl/warszawa /7,54420,25850133,koronawirus-spowiedz-bez-wysiadania-z-samochodu-pod-swiatynia.html

${ }^{22}$ https://krakow.wyborcza.pl/krakow/7,44425,25810456,watykan-zaleca-wielkanoc-bez-wspolnego-swiecenia-potraw-i-bez.html 
adorowanie Najświętszego Sakramentu w Grobie Pańskim, przestrzegając jednak wszystkich ograniczeń związanych z epidemią"23.

Podawano również, zawarte w pismach biskupów poszczególnych diecezji, szczegółowe zalecenia dotyczące obrzędów lub zwyczajów, np. obmycia nóg, procesji, aktu adoracji krzyża przez pocałunek, wystawiania straży grobowej ${ }^{24}$, czy wreszcie święcenia pokarmów ${ }^{25}$ oraz odwiedzania przez księży chorych lub świątecznych spotkań w gronie bliskich ${ }^{26}$. Redakcja zauważyła propozycję, która miałaby pomóc katolikom w jak najpełniejszym obchodzeniu Wielkiej Nocy w domu:

duchowni apelują, by zrezygnować z chodzenia na msze na rzecz transmisji radiowych, telewizyjnych i internetowych. A Wydział Duszpasterstwa Rodzin krakowskiej kurii przygotował dla katolików materiały, które mają pomóc przetrwać Wielkanoc bez wychodzenia z domów ('\#Domowe celebracje' to zbiór fragmentów Pisma Świętego, okolicznościowe modlitwy i pieśni, a także pomysły na rodzinne świętowanie) ${ }^{27}$.

Oprócz restrykcji dotyczących nabożeństw szeroko analizowano zmiany w zwyczajach, które dotyczą nie tylko praktykujących katolików. Wyróżnia się tu obszerny, w porównaniu do innych badanych tekstów, reportaż Wielkanoc odwołana. Krzysztof porozmawia z córkq na Skypie, potem otworzy butelkę wódki i sło$i k$ śledzi ${ }^{28}$. Opisane tu zostały świąteczne plany siedmiu osób, z których cztery mieszkają samotnie. Zgodnie z nagłówkiem z artykułu wyłaniał się depresyjny tytułowy bohater zmaga się z tą chorobą - obraz Polaków, którzy spędzą samotnie święta, bojąc się o przyszłość lub nie mając czasu na ich refleksyjne obchodzenie z powodu nadmiaru obowiązków zawodowych.

${ }^{23}$ https://warszawa.wyborcza.pl/warszawa/7,54420,25825760,wielkanoc-a-koronawirus-sa-juz-wytyczne-diecezji-dotyczace.html

${ }^{24}$ https://rzeszow.wyborcza.pl/rzeszow/7,34962,25827884,koronawirus-a-wielkanoc-jak-beda-wygladac-obchody-w-rzeszowskich.html

${ }^{25}$ https://kielce.wyborcza.pl/kielce/7,47262,25843475,koronawirus-to-beda-calkiem-inne-swieta-bez-swiecenia-pokarmow.html

${ }^{26}$ https://krakow.wyborcza.pl/krakow/7,44425,25835992,koronawirus-czy-moge-wyspowiadac-sie-przed-wielkanoca-co-ze.html

${ }^{27}$ https://krakow.wyborcza.pl/krakow/7,44425,25855109,bez-swiecenia-koszyka-bez-smigusa-dyngusa-koronawirus-miesza.html

${ }^{28}$ https://wyborcza.pl/duzy format/7,127290,25838638,wielkanoc-odwolana-przez-koronawirusa-krzysztof-porozmawia.html 
W zupełnie innym tonie przygotowane były artykuły, które ukazały się już w Wielki Piątek. Tym razem jeden z materiałów przedstawiał rodziny, które często mimo braku możliwości spotkania się twarzą w twarz - starają się radzić sobie z ograniczoną możliwością kontaktu. W tekście przytaczana jest nawet opinia, że młodzi ludzie mogą na tej sytuacji niewiele stracić:

Dla młodych święta online wcale nie muszą być dużo gorsze. Chcą zachować choć namiastkę tradycji - przygotowując dom, gotując wielkanocne potrawy, ale w mniejszych ilościach. - Przynajmniej zaoszczędzę na zakupach - słyszę od wielu osób $\mathrm{z}$ najbliższego otoczenia ${ }^{29}$.

W drugim przykładowym reportażu autor przedstawił inicjatywę łódzkich uczelni, które - pragnąc zapewnić studentom pozostającym na święta w akademikach namiastkę świątecznej atmosfery - dostarczyły do domów studenckich jednorazowe pojemniki z zestawem przygotowanym na wzór tradycyjnego śniadania wielkanocnego ${ }^{30}$.

Osobno informowano o dostępności cmentarzy dla odwiedzających groby. W takich tekstach nie przytaczano jednak opinii księży, ale zwracano uwagę na wytyczne administracyjne.

Wiele tekstów informacyjnych „ubarwianych” było reportażowymi fragmentami, odnoszącymi się do wspólnotowego aspektu przeżywania Wielkanocy. Cytowano wypowiedzi klientów sklepów i targowisk, np.:

Wielkanocy w tym roku nie będzie. Wnuki na święta z Wrocławia nie przyjadą, zajączka nie dostaną. To będzie pogrzeb, a nie zmartwychwstanie - macha ręką starsza kobieta, która kupuje warzywa i palmy. Chce nimi udekorować swój skromny wielkanocny stół. - Będę sama, papieża w telewizji obejrzę i się pomodlę - mówi ze smutkiem w głosie ${ }^{31}$.

Warto również przytoczyć fragmenty pierwszych pytań z wywiadu z prof. Przemysławem Rotengruberem z Uniwersytetu Adama Mickiewicza: „Nawet

${ }^{29}$ https://rzeszow.wyborcza.pl/rzeszow/7,34962,25859596,rodzinne-spotkania-na-skype-zaoszczedze-na-zakupach.html

${ }^{30}$ https://lodz.wyborcza.pl/lodz/7,35136,25860936,sniadanie-wielkanocne-w-akademikach-namiastka-swiat-w-czasie.html

${ }^{31}$ https://poznan.wyborcza.pl/poznan/7,36001,25845776,kolejki-w-dyskontach-pusto-na-targowiskach-seniorzy-zalamani.html 
ludziom niewierzącym trudno sobie wyobrazić puste kościoły w Wielkim Tygodniu. [...] Abstrahując od religijnego wymiaru, jak najbliższa Wielkanoc będzie wyglądała bez wspólnych spotkań i odwiedzin?"32. To jeden z wielu przypadków, świadczący o szerokim, nie tylko religijnym, potraktowaniu Wielkanocy przez redakcję serwisu wyborcza.pl.

Sporadycznie ukazywały się materiały dziennikarskie, zupełnie pomijające duchowy wymiar świąt, np. na temat rezygnacji z czterodniowego wyjazdu do spa i przysługującym w związku z tym prawom konsumenta ${ }^{33}$.

Istotną grupę w materiale badawczym stanowiły teksty dotyczące pochówku zmarłych i sakramentu małżeństwa. Nie zawsze były one jednak silnie związane z samą religią lub Kościołem. W przypadku obu tematów silny akcent był położony nie tyle na duchowe przeżycie wydarzeń i ich wspólnotowy charakter, co na ekonomiczne skutki dla poszczególnych branż.

Dane o zarażeniach podczas ślubów i pogrzebów były wykorzystywane w niewielu tekstach publicystycznych jako ilustracje zbyt szybkiego znoszenia obostrzeń sanitarnych, np.:

Tylko w powiecie nowosądeckim kwarantanną objętych zostało 2 tys. mieszkańców - przede wszystkim z powodu wesel właśnie. [...] Słynne już wesele w Nawojowej skończyło się 151 zakażonymi i 1 tys. osób na kwarantannie. Po pogrzebie Zofii Karpiel-Bułecki w powiecie tatrzańskim wzrosła gwałtownie liczba zakażeń. [...] Po weselu w gminie Mucharz sanepid potwierdził zakażenie u 15 gości, 300 osób przechodzi kwarantannę $e^{34}$.

Wymowne są tytuły tych opinii: Dla koronawirusa gra orkiestra weselno-pogrzebowa czy Wesela i pogrzeby z koronawirusem $w$ tle.

W tej grupie tekstów poziom nasycenia treściami lokalnymi zmieniał się wraz z występowaniem coraz większej liczby zachorowań w kraju. W późniejszym okresie materiały dziennikarskie dotyczyły głównie poszczególnych parafii. W strukturze genologicznej przeważały mniej obszerne informacje, które później ustępowały miejsca, przede wszystkim w okresie świątecznym, wiadomościom

${ }^{32}$ https://poznan.wyborcza.pl/poznan/7,36001,25836197,wielkanoc-nie-musi-byc-stypa-izolacja-lekarstwem-na-traume.html

${ }^{33}$ https://lodz.wyborcza.pl/lodz/7,35136,25843369,koronawirus-wykupilem-wyjazd-na-wielkanoc-jak-odzyskac-pieniadze.html

${ }^{34}$ https://krakow.wyborcza.pl/krakow/7,44425,26135767,wesele-z-koronawirusem.html 
z elementami reporterskimi oraz reportażom. Te dwa elementy przełożyły się również na ogólny wydźwięk neutralny artykułów oraz brak sygnałów świadczących o stronniczości tekstów.

\section{(2) POMOC DLA POTRZEBUJĄCYCH}

W tej grupie najczęściej teksty opisywały pomoc, którą organizowały lokalne oddziały Caritas. Wszystkie miały wydźwięk pozytywny, o czym świadczą same tytuły: Koronawirus. Defibrylatory trafiły do kilku podkarpackich szpitali. Sprzęt kupił Caritas Polska ${ }^{35}$, Respiratory z Caritas Częstochowa dla czterech szpitali i domu pomocy społecznej ${ }^{36}$, Koronawirus. Szczeciński Caritas i terytorialsi z paczkami dla ludzi na przymusowej kwarantannie ${ }^{37}$, Wolontariusze Caritasu robiq świąteczne zakupy seniorom. Wciąż można zgłaszać się po pomoc ${ }^{38}$.

Najbardziej interesujący jest materiał Koronawirus. Caritas rozdaje posiłki pod specjalnym nadzorem. Bezdomni nie zostali sami ${ }^{39}$. Tekst został przygotowywany w formie reportażowej, z obrazową informacją na temat udzielanej pomocy, zaznaczeniem, że odbywa się ona z zachowaniem reguł sanitarnych oraz apelem o pomoc. Opisy przeplatane były opiniami osób korzystających ze wsparcie Caritasu, a także wypowiedziami sióstr i księży. Głównym tematem materiału była praca, wykonywana przez siostry podczas spotkań z ubogimi: „Cztery siostry zakonne mają na sobie maski, rękawiczki gumowe i fartuchy ochronne. Wpuszczają na podwórko pojedynczo i każdemu mierzą temperaturę. Pilnują też, by goście nie stali blisko siebie".

Szczególny nacisk został położony na kontakt między siostrami, a potrzebującymi pomocy:

${ }^{35}$ https://rzeszow.wyborcza.pl/rzeszow/7,34962,26046835,koronawirus-defibrylatory-trafily-do-kilku-podkarpackich-szpitali.html

${ }^{36}$ https://czestochowa.wyborcza.pl/czestochowa/7,48725,26078448,respiratory-z-caritas-czestochowa-dla-czterech-szpitali-i-domu.html

${ }^{37}$ https://szczecin.wyborcza.pl/szczecin/7,34939,25810083,koronawirus-szczecinski-caritas-i-terytorialsi-z-paczkami.html

${ }^{38}$ https://poznan.wyborcza.pl/poznan/7,36001,25842065, wolontariusze-caritasu-robia-swiateczne-zakupy-seniorom-wciaz.html

${ }^{39}$ https://poznan.wyborcza.pl/poznan/7,36001,25797741,koronawirus-caritas-rozdaje-posilki-pod-specjalnym-nadzorem.html 
Jeden z bezdomnych prosi bowiem o medyczną pomoc. - Niech mi siostra pomoże, wszystkie szpitale zamknięte. Mam jodynę i bandaż - prosi błagalnym głosem i dodaje: - Za chwilę obetną mi nogę - wskazuje na ranę. - Okropnie to wygląda - przyznaje s. Józefa. Klęka i rozcina zaropiały i zakrwawiony opatrunek [...]. Siostra bez zbędnych słów obmywa nogę i robi opatrunek. Wszystko idzie szybko i w maksymalnym skupieniu. Siostry dają mężczyźnie czyste spodnie oraz wykupują receptę na antybiotyk. - Dziękuję - mówi pełen wdzięczności.

Zaprezentowane są również codzienne, bliskie czytelnikowi problemy zakonnic. Jedna z nich przyjechała do Poznania dwa tygodnie wcześniej, sądząc, że będzie miała tu więcej czasu na napisanie pracy magisterskiej. Mimo że podkreśla, iż „pomoc drugiemu człowiekowi jest teraz najważniejsza”, przyznaje również, że pandemia pokrzyżowała jej plany.

Osobny cykl artykułów dotyczył akcji „Zanurzeni w miłości. Respiratory dla szpitali”, której współorganizatorem także był Caritas. W tekstach podkreślano, że na cel zostanie przeznaczona całość zebranej kwoty ${ }^{40}$, a w ciągu „trzech tygodni organizatorom akcji udało się zebrać ponad $2 \mathrm{mln}$ zł dla szpitali walczących z koronawirusem ${ }^{41}$ ". Dołączano także apel o przyłączenie się do akcji.

Kilkakrotnie informowano czytelników o kolejnych przypadkach COVID-19 wśród personelu i osób korzystających z pomocy centrów Caritasu, szczególnie w Warszawie. Przyczyny takiej sytuacji nie były analizowane czy oceniane. Publikowano natomiast apele o pomoc ${ }^{42}$.

W pojedynczych materiałach opisywane były inne akcje. Szczególnie interesujący jest reporterski tekst, w którym relacjonowano wydawanie posiłków przez zakonników z bydgoskiego Stowarzyszenia Miłosierdzia św. Wincentego a Paulo ${ }^{43}$. Podobnie jak w przypadku cytowanego wyżej artykułu o siostrach elżbietankach z Poznania, tak w tym przypadku osią reportażu było ukazanie bezpośredniego

\footnotetext{
${ }^{40}$ https://rzeszow.wyborcza.pl/rzeszow/7,34962,25858824,duchowni-zbieraja-pieniadze-na-respiratory-w-dzien-zdobyli.html

${ }^{41}$ https://rzeszow.wyborcza.pl/rzeszow/7,34962,25882601,ksieza-z-koszalina-zebrali-pieniadze-na-kolejny-respirator-dla.html

${ }^{42}$ https://warszawa.wyborcza.pl/warszawa/7,54420,25864582,koronawirus-w-osrodku-caritasu-w-warszawie-potrzebna-pilna.html; https://warszawa.wyborcza.pl/warszawa /7,54420,25867959,na-oddziale-z-koronawirusem-w-osrodku-caritas-na-krakowskim.html

${ }^{43}$ https://bydgoszcz.wyborcza.pl/bydgoszcz/7,48722,25820438,dym-z-kuchni-kosciola-brakuje-pieniedzy-na-posilki-dla-bezdomnych.html
} 
kontaktu z potrzebującymi i realnego życia najbardziej potrzebujących, często oddalonego od odgórnych wytycznych. Tak proboszcz parafii tłumaczył, dlaczego nie są wydawane zupy, mimo że ich przygotowywanie byłoby łatwiejsze:

Bezdomni to w większości alkoholicy, ręce im się trzęsą, delirium po prostu. Jeśli dostaną zupę w plastikowym talerzu, to jej po prostu nie doniosą w ustronne miejsce, gdzie chcą się posilić. Tutaj się wstydzą [...]. Gotujemy posiłki stałe [...]. To, co łatwiej utrzymać w dłoniach.

Inne teksty na temat przedsięwzięć organizowanych przez instytucje związane z Kościołem opisywały np. szycie maseczek przez siostry karmelitanki bose ze Spręcowa pod Olsztynem ${ }^{44}$, zbiórkę w diecezji zielonogórsko-gorzowskiej na pomoc lubuskim szpitalom ${ }^{45}$, zakup przez Katolicki Uniwersytet Lubelski karetki dla Szpitala Jana Bożego ${ }^{46}$, czy zebranie w okolicznych parafiach 25 tys. zł dla Domu Dziecka w Krasnem pod Supraślem ${ }^{47}$.

Omówiony wyżej zestaw tekstów składał się w większości z krótkich wiadomości. Wszystkie materiały miały charakter lokalny oraz pozytywny wydźwięk. Nie odnotowano wyrażonych wprost opinii odautorskich, choć sposób prowadzenia narracji w dłuższych artykułach wskazywał na poparcie akcji pomocowych.

\section{(3) BEZPIECZEŃSTWO I KONTROWERSJE}

W tej grupie najbardziej dramatyczne relacje dotyczyły przypadków zarażenia koronawirusem wśród sióstr zakonnych. Doniesienia były tym tragiczniejsze, że siostry opiekowały się zazwyczaj pensjonariuszami domów pomocy społecznej, którzy ze względu na wiek byli szczególnie zagrożeni skutkami choroby. W pierwszych dwóch tygodniach maja ukazał się cykl artykułów, w których opisywano na bieżąco sytuację w kilku domach zakonnych Zgromadzenia Sióstr Miłosierdzia

\footnotetext{
${ }^{44}$ https://olsztyn.wyborcza.pl/olsztyn/7,48726,25811786,koronawirus-na-warmii-i-mazurach-siostry-zakonne-szyja-maseczki.html

${ }^{45}$ https://zielonagora.wyborcza.pl/zielonagora/7,35182,25865102,koronawirus-i-jalmuzna-wielkanocna-ksieza-zebrali-176-tys.html

${ }^{46}$ https://lublin.wyborcza.pl/lublin/7,48724,25892152,koronawirus-wystarczylo-9-dni-zbiorki-szpital-jana-bozego.html

${ }^{47}$ https://bialystok.wyborcza.pl/bialystok/7,35241,26084070,koronawirus-metropolita-i-duchowni-wsparli-dom-dziecka-w-krasnem.html
} 
św. Wincentego a Paulo. Zmarło wtedy sześć sióstr z Chełma ${ }^{48}$, choroba została stamtąd zawleczona do poznańskiego domu sióstr szarytek ${ }^{49}$, gdzie zmarła jedna z nich ${ }^{50}$.

Podobną sytuacje opisywał cykl tekstów na temat zarażeń w DPS-ie prowadzonym we Wrocławiu przez Zgromadzenie Sióstr Maryi Niepokalanej. Tutaj autor, cytując anonimowego informatora, opisuje dramatyczną sytuację, kiedy siostry i pensjonariusze nie znali wyników testów, co sprawiło, że nie wprowadzono zasad kwarantanny. Używane są sformułowania „sprawa wyszła przypadkowo"51 i „mieszkanki domu i personel nie zostali ostrzeżeni”52. Mimo braku jednoznacznych ocen wydźwięk tych artykułów określić można jako empatyczny, a autor odpowiedzialnością obarcza procedury - biorąc siostry w obronę.

„Gazeta Wyborcza” informowała o przypadkach zamykania poszczególnych kościołów dla wiernych z powodu kwarantanny lub choroby księży w domach zakonnych. W przypadku wspomnianych już wyżej dominikanów z Katowic w artykule podkreślono, że już wcześniej prosili oni, aby wierni nie przychodzili na msze, ponieważ księża nie są w stanie zapewnić spełnienia restrykcyjnych norm liczby osób obecnych w kościele ${ }^{53}$.

W większości z tekstów przytaczano wypowiedzi duchownych, którzy zapewniali, że w kościołach przestrzegane były procedury sanitarne, a po wykryciu ogniska choroby świątynie były dezynfekowane. Apelowano również do wiernych, którzy mieli kontakt z duchownymi, u których stwierdzono obecność koronawirusa, o zgłaszanie się do stacji sanepidu ${ }^{54}$ lub „podjęcie odpowiednich kroków sanitarnych”55.

${ }^{48}$ https://torun.wyborcza.pl/torun/7,48723,25952159,koronawirus-w-kujawsko-pomorskiem-smierc-ktorej-nie-ma-w-statystykach.html

${ }^{49}$ https://poznan.wyborcza.pl/poznan/7,36001,25918375,siostra-szarytka-byla-w-chelmnie-i-tamtad-przywiozla-koronawirusa.html

${ }^{50}$ https://poznan.wyborcza.pl/poznan/7,36001,25987326,koronawirus-192-nowe-zakazenia-w-polsce-i-8-w-wielkopolsce.html

${ }^{51}$ https://wroclaw.wyborcza.pl/wroclaw/7,35771,26198068,kuronawirus-u-siostr-marianek-i-placowkach-ktore-prowadza.html

${ }^{52}$ https://wroclaw.wyborcza.pl/wroclaw/7,35771,26219249,duze-ognisko-koronawirusa-we-wroclawskim-dps-prowadzonym-przez.html

${ }^{53}$ https://katowice.wyborcza.pl/katowice/7,35063,25806616,dominikanie-z-katowic-objeci-kwarantanna-kosciol-jednak-bedzie.html

${ }^{54}$ https://kielce.wyborcza.pl/kielce/7,47262,26127143,koronawirus-ksiadz-zakazony-sanepid-prosi-wiernych-o-kontakt.html

${ }^{55}$ https://warszawa.wyborcza.pl/warszawa/7,54420,26372232,koronawirus-u-paulinow-kosciol-swietego-ducha-zamkniety.html 
Dwukrotnie informowano o przekroczeniu limitu osób przebywających w kościele. 29.03 w kościele w Dąbrowie Białostockiej zebrało się kilkudziesięciu wiernych ${ }^{56}$. W pierwszym tygodniu kwietnia policja została wezwana do kościoła w Sieradzu oraz do dwóch interwencji w kościołach powiatu opoczyńskiego. W drugim przypadku

sygnał o tym, że wiernych na mszy świętej jest więcej, niż zakładają regulacje związane z epidemią koronawirusa, mundurowi dostali od samych uczestników nabożeństw. [...] księża odmówili przyjęcia mandatu. Policjanci postanowili więc sporządzić wnioski do sądu o ukaranie księży ${ }^{57}$.

W serwisie wyborcza.pl znajdowały się także informacje na temat wydarzeń negatywnie ocenianych przez wiernych lub samych księży. W tekście na temat banerów, wywieszonych na ogrodzeniu kościoła Zgromadzenia Misjonarzy Oblatów Maryi Niepokalanej w Katowicach, przytoczono widniejące na nich hasła: „Nie cytryna, nie malina, ale Bóg i Dobra Nowina. Wstąp i wzmocnij swoją odporność", „Nie pomogły suplementy, sięgnij po sakramenty”, „Nie ma odporności bez Bożej Miłości”, „Nim corona cię nawiedzi, idź do spowiedzi!”. Proboszcz parafii zapewniał, że „intencją nie było bagatelizowanie pandemii, ale nabranie dystansu wobec strachu z jej powodu. [...] - W kościele przestrzegamy i innych prosimy o przestrzeganie powszechnych obecnie zasad ostrożności: zakładanie maseczek, dezynfekcję, odstępy między osobami" ${ }^{58}$. Dziennikarz cytuje również parafianina, który tłumaczy decyzję księży: „Znam proboszcza i innych ojców od lat i wątpię, żeby chcieli namawiać ludzi do [...] zastąpienia lekarzy sakramentami".

W kościele Maryi Królowej na Rynku Wildeckim w Poznaniu, proboszcz, bez konsultacji z konserwatorem zabytków, wywiesił na wieży banery z napisem „Modlimy się i tęsknimy za Wami! - wasi kapłani". Urzędnicy wezwali księdza do usunięcia plakatów. „Zapomniałem, nie pomyślałem, że powinienem działać w tej kolejności. [...] Chciałem jakoś ulżyć parafianom. Zrobiłem to spontanicznie. To nie było złośliwe działanie" - tłumaczył proboszcz. W wymienionych wyżej tekstach,

${ }^{56}$ https://bialystok.wyborcza.pl/bialystok/7,35241,25829007,koronawirus-kilkudziesieciu-wiernych-na-mszy-w-dabrowie-bialostockiej.html

${ }^{57}$ https://lodz.wyborcza.pl/lodz/7,35136,25849694,koronawirus-i-kosciol-niemal-pol-setki-osob-na-mszy-zamiast.html

${ }^{58}$ https://katowice.wyborcza.pl/katowice/7,35063,26361625,nim-corona-cie-nawiedzi-idz-do-spowiedzi-banery-na-plocie.html 
negatywnym wypowiedziom osób skarżących się na działanie księży przeciwstawione były opinie odmienne lub usprawiedliwiające.

Bardziej jednoznaczne i bezkompromisowe stanowiska przedstawiały trzy artykuły omówione poniżej. Były one relacjami wypowiedzi jednoznacznie zdeklarowanych ideologicznie osób, które zabrały głos na tematy wzbudzające emocje i kontrowersje.

Pierwszy z nich był omówieniem wypowiedzi bp. Ignacego Deca podczas mszy z okazji 16. rocznicy ustanowienia diecezji świdnickiej. Tytuł tekstu odpowiednio streszczał jego treść: Kto jest winny epidemii koronawirusa? Według biskupa Deca - lewacy, feministki $i$ „czarne marsze ${ }^{\prime 59}$. W materiale cytowana była m.in. wypowiedź biskupa, w której pytał on: „Może to jest Boże upomnienie? Niektórzy mówią, że to jest kara Boża, to, co się dzisiaj dzieje”.

\section{Niezależnie od sposobu ujęcia tematu redakcja serwisu wyborcza.pl interesowała się wpływem pandemii na funkcjonowanie Kościoła oraz sposobem realizacji praktyk i zwyczajów religijnych przez wiernych.}

W drugiej publikacji redakcja streściła wpis na prywatnej stronie Leszka Sosnowskiego, w którym obliczał on, ile osób może na tej samej powierzchni przebywać w kościele, a ile w autobusie komunikacji miejskiej, dodając, że taka sytuacja świadczy o tym, iż „okres epidemii jest wykorzystywany do dalszej ateizacji społeczeństwa".

Trzeci tekst to omówienie listu otwartego posłanki Joanny Senyszyn do premiera Mateusza Morawieckiego. Także w tym przypadku tytuł - Koronawirus. Senyszyn pisze do Morawieckiego: „Zamknijcie kościoły, biskupi nie zdali egzaminu" ${ }^{\prime \prime 0}$ - oddawał treść materiału. Wymowny był ostatni akapit tekstu: „'Panie

${ }^{59}$ https://wroclaw.wyborcza.pl/wroclaw/7,35771,25826522,biskup-koronawirusa-zestawia-z-aborcja-i-eutnazja-moze-to.html

${ }^{60}$ https://trojmiasto.wyborcza.pl/trojmiasto/7,35612,25789017,poslanka-sld-apeluje-do-premiera-zamknijcie-koscioly.html 
Premierze, Ministrowie! Nie lękajcie się kleru! W trosce o życie i zdrowie Polaków zamykajcie kościoły! To Wasz obowiązek' - apeluje Senyszyn".

Wszystkie trzy przywołane wyżej materiały dziennikarskie zbudowane są wg tego samego modelu. Składają się ze streszczeń i cytatów ogólnodostępnych publikacji. Każdy z artykułów opatrzony jest prowokującym, jednak informacyjnym tytułem. Jednocześnie materiały pozbawione są jakiejkolwiek wprost wyrażonej oceny słów wypowiadanych przez bohaterów.

Podobnie jak w poprzednim zestawie tekstów, także w tym przypadku zdecydowanie dominowały informacje lokalne. W odróżnieniu od wcześniejszych grup tematycznych, tutaj istotna część materiałów posiada wydźwięk negatywny. Krytykowane są działania Kościoła jako całości oraz poszczególnych osób duchownych. W artykułach dotyczących konfliktów dziennikarze zachowywali jednak równowagę, umieszczając wypowiedzi obu stron sporu.

\section{WNIOSKI}

Wyniki analizy pokazują, że niezależnie od sposobu ujęcia tematu redakcja serwisu wyborcza.pl interesowała się wpływem pandemii na funkcjonowanie Kościoła, sposobem realizacji praktyk i zwyczajów religijnych przez wiernych, a także oddziaływaniem zmian na życie Polaków niezwiązanych bezpośrednio z Kościołem. Jest to o tyle istotne, że serwis nie spełnia żadnego z wyznaczników, które pozwalałyby zaklasyfikować go do grupy mediów katolickich: nie posiada ani wsparcia i związków finansowych z Kościołem, ani nadzoru władzy kościelnej ${ }^{61}$.

W istotnej części materiałów wymieniano ograniczenia w odbywaniu praktyk religijnych łącznie $\mathrm{z}$ innymi restrykcjami, wprowadzanymi np. w działalności placówek handlowych. Analizy ekonomiczne i społeczne wskazują, że wszystkie dziedziny życia są silnie powiązane z sektorem ochrony zdrowia. Zaheer Allam, opisując trzecie 50 dni pandemii (od 9 marca do 28 kwietnia 2020 r.), jako w tym czasie zamrożone wymienia na równi sektory sportowy, rozrywkowy i religijny ${ }^{62}$. Efekt ten nie jest wyjątkowy dla COVID-19. W przypadku grypy hiszpanki, sto

${ }^{61}$ D. Guzek, Konwergencja mediów katolickich $w$ Polsce, w: M. Gierula, P. Szostok (red.), Konwergencja mediów masowych i jej skutki dla współczesnego dziennikarstwa, t. 2, Wydawnictwo Uniwersytetu Śląskiego, Katowice 2012, s. 228.

${ }^{62}$ Z. Allam, Surveying the Covid-19 Pandemic and its implications. Urban health, data technology and political economy, Elsevier, Amsterdam 2020, s. 41 
lat wcześniej, również stosowano równomierne zasady kwarantanny - dotyczące zarówno kościołów, jak i kin oraz teatrów ${ }^{63}$, a także barów i salonów fryzjerskich $^{64}$. W analizowanym materiale nie odnotowano jednak prostych porównań kościołów do sklepów czy restauracji, a raczej wspólny opis wprowadzania lub łagodzenia kolejnych ograniczeń. Korelacja między tymi treściami wynikała z łączenia ich w konkretnych regulacjach prawnych (ogłaszanych i wprowadzanych przez rząd).

Nie stwierdzono sygnałów świadczących o jednoznacznej stronniczości redakcji w kwestiach światopoglądowych, które pozwalałyby na opis materiału badawczego pod tym kątem.

Wydaje się, że najważniejsze były tu trzy przyczyny. Pierwsza to struktura genologiczna analizowanych tekstów, jak i całego korpusu. Zdecydowaną większość stanowią newsy niezawierające elementów publicystycznych lub informacje uzupełnione o elementy reportażu, o wiele mniej jest artykułów, które można sklasyfikować jako publicystykę. Wniosek ten jest zbieżny z wynikami badań wizerunku Kościoła katolickiego w polskiej prasie ${ }^{65}$, wg których np. jednoznacznie krytyczne oceny o wiele łatwiej odnaleźć w artykułach publicystycznych i tygodnikach opinii.

Jednym z podstawowych wskazań etycznych i warsztatowych, wpływających na praktykę redakcyjną jest zasada, wg której dziennikarze powstrzymują się od komentowania publikowanych informacji ${ }^{66}$. Wydaje się, że realizacja tego wymogu, zgodnego ze współczesnymi standardami dziennikarstwa, była drugim elementem, który wpłynął na niewystępowanie wyraźnego nachylenia światopoglądowego w analizowanych tekstach. Świadczy o tym brak odautorskich komentarzy zarówno w materiałach o wydźwięku pozytywnym, jak i negatywnym.

Trzecią przyczyną był globalny wymiar kryzysu. Kościół - podobnie jak inne społeczności, instytucje i organizacje - staje się atrakcyjnym tematem dla

${ }^{63}$ H. Phillips, D. Killingray, The Spanish influenza pandemic of 1918-1919. New perspectives, Routledge, Londyn 2011, s. 152.

${ }^{64}$ N. Johnson, Britain and the 1918-19 influenza pandemic. A dark epilogue, Routledge, Milton Park 2006, s. 122.

${ }^{65}$ J. Szulich-Kałuża, Kreowanie wizerunku Kościoła katolickiego w dyskursie polskiej prasy, „Biuletyn Edukacji Medialnej” 2018 nr 2, s. 69-81.

${ }^{66}$ W. Pisarek, Kodeks etyki dziennikarskiej, w: Z. Bauer, E. Chudziński (red.), Dziennikarstwo i świat mediów, Universitas, Kraków 2000, s. 429-430. 423-434; M. Chyliński, S. Russ-Mohl, Dziennikarstwo, Grupa Wydawnicza Polskapresse, Warszawa 2008, s. 65. 
mediów, kiedy dochodzi w nim do wydarzeń mających znamiona skandalu lub kontrowersji ${ }^{67}$. W sytuacji ogólnego kryzysu sytuacja uległa jednak złagodzeniu, ponieważ głównym tematem newsów był rozwój pandemii COVID-19 i jego skutki dla czytelników.

Fakt, że nie stwierdzono ocen sformułowanych przez dziennikarzy wprost, nie oznacza, że takich ocen nie było w ogóle. Wśród sygnałów negatywnych można wymienić dobór tematyki oraz kontrowersyjnych wypowiedzi. Jako pozytywne można uznać zachęcanie do wspierania akcji organizowanych przez instytucje kościelne i reportażowe relacje $\mathrm{z}$ akcji dla potrzebujących. $\mathrm{W}$ tekstach zawierających zarzuty pod adresem księży dziennikarze zamieszczali wypowiedzi obu stron konfliktu.

\section{Widoczna, szczególnie po dotarciu choroby do Polski, była silna tendencja do przedstawiania wydarzeń lokalnych. Relacjonowano nawet sytuację w konkretnych kościołach.}

Niemniej jednak należy również zaznaczyć, że odnotowano teksty, w których nagłówki nie odpowiadały treści, reprezentując elementy stylu tabloidowego. Np. w wiadomości Zamknięte granice, kościoły, restauracje. Nie będzie pociagów do Berlina $^{68}$ wyliczono restrykcje, w tym ograniczenia liczby wiernych podczas nabożeństw, brak natomiast informacji o jakimkolwiek zamkniętym kościele.

Widoczna, szczególnie po dotarciu choroby do Polski, była silna tendencja do przedstawiania wydarzeń lokalnych. Np. relacjonowano sytuację w konkretnych kościołach. Wynik ten jest efektem wzrostu liczby potwierdzonych przypadków COVID-19 w całej Polsce oraz aktywnego działania regionalnych oddziałów „Gazety Wyborczej".

${ }^{67}$ M. Przybysz, Kościół $w$ social media. Komunikacja instytucji eklezjalnych $w$ mediach społecznościowych w perspektywie medioznawczej i teologicznej, „Kultura - Media - Teologia” $2018 \mathrm{nr} 35$, s. 142-143.

${ }^{68}$ https://zielonagora.wyborcza.pl/zielonagora/7,35182,25788775,zamkniete-granice-koscioly-restauracje-nie-bedzie-pociagow.html 


\section{BIBLIOGRAFIA}

Allam Z., Surveying the COVID-19 pandemic and its implications. Urban health, data technology and political economy, Elsevier, Amsterdam 2020.

Azzoni T., Dampf A., Game Zero: Spread of virus linked to Champions League match, The Associated Press z 25.02.2020, https://apnews.com/article/ae59cfc0641fc63afd09182bb832ebe2 (dostęp: 1.10.2020 r.).

Bieler D., "A biological bomb": Champions League match in Italy linked to epicentre of coronavirus outbreak, The Independent, z 25.03.2020 r., https://www.independent. co.uk/news/world/coronavirus-italy-champions-league-atlanta-valencia-milanbergamo-a9426616.html (dostęp: 1.10.2020 r.).

Breitnauer J., The Spanish flu epidemic and its influence on history. Stories from the 1918-1920 Global Flu Pandemic, Pen \& Sword History, Barnsley 2019.

Brzoza, K., Głuszek-Szafraniec, D., Szostok, P., Upolitycznienie przekazu prasowego w wybranych polskich tygodnikach opinii. Wstępny raport z badań, „Political Preferences” 2017 nr 16, s. 81-106.

Chyliński M., Russ-Mohl S., Dziennikarstwo, Grupa Wydawnicza Polskapresse, Warszawa 2008.

Guzek D., Konwergencja mediów katolickich w Polsce, w: M. Gierula, P. Szostok (red.), Konwergencja mediów masowych i jej skutki dla współczesnego dziennikarstwa, t. 2, Wydawnictwo Uniwersytetu Śląskiego, Katowice 2012, s. 227-240.

Honigsbaum M., Living with Enza. The forgotten story of Britain and the great flu pandemic of 1918, Springer, Basingstoke 2016.

Johnson N., Britain and the 1918-19 influenza pandemic. A dark epilogue, Routledge, Milton Park 2006.

Kubacka A., Wartościowanie Kościoła - czy Kościół jest wartością?, „Słowo. Studia Językoznawcze" 2019 nr 10, s. 94-101.

Kunczik M., Zipfel A., Wprowadzenie do nauki o dziennikarstwie i komunikowaniu, tłum. J. Łoziński, W. Łukowski, Scholar, Warszawa 2000.

Lynteris Ch., Human extinction and the pandemic imaginary, Routledge, Londyn 2020.

Mazzini M., Od tego się zaczął włoski dramat? Wirus na stadionie, Polityka z 24.03.2020, https://www.polityka.pl/tygodnikpolityka/swiat/1949048,1,od-tego-sie-zaczalwloski-dramat-wirus-na-stadionie.read (dostęp: 1.10.2020 r.).

Moeller S. D., Compassion fatigue. How the media sell disease, famine, war and death, Routledge, Nowy Jork 2002.

Nicolaides A., Członek WHO potwierdza: To wydarzenie rozprzestrzeniło koronawiru$s a$, Radio Zet z 25.03.2020, https://sport.radiozet.pl/Pilka-nozna/Liga-Mistrzow/ WHO-potwierdza-Mecz-Atalanta-Valencia-rozprzestrzenil-koronawirusa (dostęp 1.10.2020 r.)

Phillips H., Killingray D., The Spanish influenza pandemic of 1918-1919. New perspectives, Routledge, Londyn 2011. 
Pisarek W., Kodeks etyki dziennikarskiej, w: Z. Bauer, E. Chudziński (red.), Dziennikarstwo i świat mediów, Universitas, Kraków 2000, s. 423-434.

Poniński A., O Kościele w „Gazecie Wyborczej” w latach 1989-1993, „Studia Włocławskie” $2005 \mathrm{nr}$ 7, s. 267-276.

Przybysz M., Kościół w social media. Komunikacja instytucji eklezjalnych $w$ mediach społecznościowych $w$ perspektywie medioznawczej i teologicznej, „Kultura- Media - Teologia" 2018 nr 35, s. 140-166.

Shin H., Young Yi H., Secretive church at center of South Korea's explosive coronavirus outbreak, Reuters z 27.02.2020, https://www.reuters.com/article/us-china-health-southkorea-church/secretive-church-at-center-of-south-koreas-explosivecoronavirus-outbreak-idUSKCN20L0Q8 (dostęp: 1.10.2020 r.).

Szulich-Kałuża J., Kreowanie wizerunku Kościoła katolickiego $w$ dyskursie polskiej prasy, „Biuletyn Edukacji Medialnej” 2018 nr 2, s. 69-81.

Wolny-Zmorzyński K., Kaliszewski A., Snopek J., Furman W. Prasowe gatunki dziennikarskie, Poltext, Warszawa 2014.

Yuan J., Burials on Hart Island, where New York's unclaimed lie in mass graves, have risen fivefold, The Washington Post z 16.04.2020, https://www.washingtonpost.com/ national/hart-island-mass-graves-coronavirus-new-york/2020/04/16/a0c413ee-7f5f-11ea-a3ee-13e1ae0a3571_story.html (dostęp: 1.10.2020 r.).

\section{Biogram}

Krzysztof Flasiński - doktor nauk o mediach i komunikacji społecznej, adiunkt w Instytucie Literatury i Nowych Mediów na Uniwersytecie Szczecińskim. Wcześniej dziennikarz w redakcjach prasowych i internetowych. Zainteresowania badawcze: zastosowanie technologii związanych z big data w analizie ilościowej i jakościowej mediów masowych. ORCID: 0000-0003-2977-2752 